\title{
The Women's Role in Public Leadership: The Experience of PCNA of West Jenangan, Ponorogo
}

\author{
Katni $^{*}$, Sigit Dwi Laksana ${ }^{1}$, Puput Wulandari ${ }^{1}$ \\ ${ }^{1}$ Universitas Muhammadiyah Ponorogo, Ponorogo, Indonesia \\ *Corresponding author. Email: katni2459@gmail.com
}

\begin{abstract}
This paper discusses the role of women's pioneering in public leadership at the organization of the Branch Management of Aisyiyah of West Jenang, Ponorogo, East Java, Indonesia. Women as pioneers of social movements at both the sub-district and village levels, collaborate intensively with various parties, provide guidance to members, coordinate with mosques and prayer rooms, develop the community economy by forming entrepreneurial communities. In this context, women's pioneering in public leadership is an interesting study to be discussed in this paper. This type of research is qualitative. Data collection techniques used in-depth interview techniques, observation, and documentation. The analytical technique used is descriptive-analytical. The findings of this study are (1) the role of women's pioneering in public leadership in Islamic community organizations has implemented its leadership function, with the implementation of POAC namely Planning, Organizing, Acting, controlling; (2) supporting factors are that women are allowed in social roles by husbands, solid teams, as well as getting support from the community, while the obstacle is the lack of cadres, the management has a dual role domestic and public; and (3) women's pioneering in public leadership is increase in the branches of Islamic community organizations, the existence of self-development in the field of organizational management, public speaking, the ability of community management with various innovative activities.
\end{abstract}

Keywords: woman, public leadership, community, PCNA, social movement

\section{INTRODUCTION}

Patriarchal culture still dominates the fabric of Indonesian society. This can be found in various aspects of economic life, education, politics, and law. As a result, various social problems emerge that fetter women's freedom and violate the rights that women should have. The role of women is still considered too domestic [1]. Women in carrying out their roles in society depend on the culture of the society in which they live, the domestic role is more borne by women $[2]$.

Other than the custom above in the West Jenangan Village, Jenangan District, Ponorogo Regency, women have a significant public leadership role, this was pioneered by Muhammadiyah's autonomous organization, Nasyiatul Aisyiyah. This is in accordance with the statement of love about women's empowerment or empowerment of womendirected to develop and mature various potentials that exist in women that make it possible to take advantage of the same rights and opportunities as men [3].

The role of women's pioneering needs to be educated through various institutions, both formal and non-normal. Education is not only in the school environment but can be achieved wherever the existence of humans is both within the family or community, in which there is a social organization. Based on the results of Karen Longman's research that women who are involved in community organizations, will tend to have the desire to be the leader of the community organizations where she lives [4].

Humans apart from being the main supporters of one of them made as a caliph or leader in the organization, Allah wants to test humans through the making of humans as caliphs and if successful, it will also be increasingly noble human degrees on the side of Allah Almighty. In this context, there is no specificity that only men can be a leader. Actual women in this case also have the same rights and opportunities in the public sector. One example of its foundation is found in the word of God in the Qur'an Surah Al-Baqarah verse 30 which means. "Remember when your Lord said to the angels:" Verily, I want to make a caliph on the face of the earth. "They asserted:" Why do you want to make a caliph on the earth who will cause damage to him and spill blood. Even though we always glorify by praising you and purifying you? "Allah says:" I truly know what you do not know. "(Q.S. Al-Baqarah verse 30) [5].

Leadership actually exists in the structure of life in the universe, especially with regard to human matters. Meanwhile, the analytical terminology of religion is not something absolute, unlimited, but rather a trustworthy or divine trust that will be accounted for later [6]. Anyone who ventured and was able and capable of being responsible and able to carry out the mandate, then he deserves to be and be called a leader. The responsibility as a leader is when someone is chosen by his community to guide and show the path in Allah allowance to the one, he leads.

The leadership of a leader greatly influences the direction and motion of the organization in totality [7]. If women are able to prove the role of their public pioneering in leading for example in terms of public communication, public relations, being able to set an example, motivate and move 
their members, then the appreciation of he will get the community of women and men.

The role of women's leadership is highly expected in society so that all elements that will run smoothly. Such as routine study activities, PKK activities, health dialogue, and others, which are related to women obligations. If the elements of both men and women move together in the community, so the activities will be well coordinated. Seeing the history of Siti Khadijah who helped the Prophet's propaganda in the spread of Islam, Siti Khadijah gave all of her possessions to Islam. This proves that the role of women is highly expected in both the Islamic religion and Islamic society [8].

In the process of organizational development, the success of a leader in improving the quality of the organization can be seen from his ability to develop the organization. Leaders are key to developing the quality of community organizations [9].

Based on studies conducted by researchers, that the leadership of women in the West Jenangan Village, Ponorogo is active in a variety of missionary guidance activities, women's organizations, and social both at either District level or Village level which was spearheaded by the Branch Leader Nasyiatul Aisyiyah. Women's organizations namely the Head of the Nasyiatul Aisyiyah Branch of West Jenangan, which is then abbreviated as PCNA, West Jenangan is a place for the community to develop their potential in organizing, such as training the mental and creativity of the community in dealing with problems in organizing and public speaking, managing women in the surroundings of West Jenangan.

In this organization, members will gain various knowledge and experience that not only has a domestic role as a housewife, but various community activities will follow activities within the organization or work programs that have been popularized and in affirming the existence and role and pioneering of women can be developed well. This makes the researcher interested to study more deeply about the role of women's pioneering in public leadership and the development of Islamic community organizations in the experience of PCNA in west Jenangan Ponorogo, East Java, Indonesia.

\section{METHODS}

This research uses a qualitative approach. Qualitative research is the process of valuation obtained in the form of explicit data or words from someone and observable behavior [10].

Sources of data conducted in this study are the words and actions of people observed or interviewed are the main data sources that are recorded through written notes, taking photographs and observations. Informants from PCNA leaders, secretaries, members, communities and community leaders. PCNA documentation which includes a description of the research location, other documents such as photographs, written documents related to the study.

Data collection techniques in this study are: 1) interviews. Interview techniques used in this study are structured interviews in which the researcher asks several questions indepth about the focus of the problem to the maximum [11]. Interviews were conducted with the head of the Nasyiatul branch 'Aisyiyah, west Jenang Ponorogo, secretaries, members, communities and community leaders, 2) observation is used to find out how women's leadership in developing Islamic community organizations in West Jenangan Ponorogo [12]. The initial step taken is to observe how the role of women's leadership in developing Islamic community organizations, then the supporting and inhibiting factors and how the results of women's leadership in developing Islamic community organizations, 3) Documentation was used by researchers to obtain data on PCNA West Java Ponorogo activities as well as facilities and infrastructure [13], and 4) Field Notes. Field notes are a supporting tool for recording important data that does not appear in the observation and interview forms [14]. This process is carried out when the observation or interview is finished. In the field notes can not only be arranged based on mere memorization because the discovery of the theory there must be real support that is not only supported by memory. The analysis technique data uses the concept of Milles a Huberman. In this study, researchers used a test of the validity of data triangulation techniques, checking the validity of data that uses something else outside of the data for the purposes of checking or comparing data. This technique can be searched by comparing observational data with interview data, comparing interview results from one informant with other informants, comparing interview results with related documents [15]. The researcher crosschecked the interview data of PCNA leaders, secretaries, members, communities, and community leaders.

\section{RESULTS AND DISCUSSION}

\subsection{The Role of Women's Pioneering in Public Leadership and Development of Islamic Community Organizations PCNA Experience West Jenangan Ponorogo, East Java, Indonesia}

Nasyiatul Aisyiyah was an Islamic-based women's philanthropic institution that was under Aisyiyah (Muhammadiyah women's movement) until 1965 [16]. When Muhammadiyah granted autonomy to Nasyiah. Since its establishment, Nasyiah has focused on developing philanthropic activities. Nasyiatul Aisyiyah's activities play a significant role in empowering women in the community, there are at least 4 (four) philanthropic preferences namely self-actualization, women's empowerment, social entrepreneurship, and social welfare.

Based on research that researchers have done, the role of women's pioneering in public leadership and the development of Islamic community organizations Nasyiatul Aisyiyah's experience in West Jenang is as follows. 


\subsubsection{Planning}

Check on the planning side that Nasyiatul Aisyiyah west Jenangan has made good planning. Planning is carried out starting from the arrangement of work meetings that produce work programs for a period of 5 years and is broken down in each year of the stage. At the working meeting the decision is taken and set various goals in organizational development that will be achieved within a predetermined time period and in accordance with the implementation procedures of the program that has been made. Program planning uses tools to achieve organizational goals to be effective and efficient. This is in line with Allison's statement that an important tool that can help nonprofit organizations to achieve their purpose. But the effectiveness of the tool ultimately depends on how well the tool is held [17].

\subsubsection{Organizing}

Organizing is the second function in management [18]. Organizing is a process of organizing the organizational structure in accordance with its objectives, resources, and environment. In the organizational aspect, the head of the Nasyiatul 'Aisyiyah branch first formed an organizational structure along with making work programs in each of their respective fields. This organizational structure starts from the highest ranks, namely the leader or chairman of the organization, vice chairman, secretary, and vice secretary, treasurer and vice treasurer, then there are members who are divided into several departments. The core organization is given their respective duties and functions so that they practice to carry out their duties and functions in accordance with effective and efficient organizational guidelines.

\subsubsection{Movement or encouragement}

After the management and work program has been designed as a non-profit Islamic women's organization [19] the head of the Nasyiatul Aisyiyah Branch carries out activities as planned or compiled. The schedule is made so that the activities are more systematic and directed. Before carrying out the work program the leader holds a structured meeting with all members or parties concerned. The point is to update the extent to which the organization is developing and to bring up new ideas, innovations, and creations in the process of organizational development. At the meetings of the leader also provides motivation for members to work to carry out their duties in accordance with their duties and responsibilities and communicate all work with the entire work team, so that they have enthusiasm, perception and measured and solid work.

\subsubsection{Supervision}

In order for organizations to have high performance, supervision is needed [20]. Supervision is carried out by providing weekly and monthly evaluations. This is intended to facilitate the supervision of the management or members and every activity carried out by Nasiyatul Aisyiyah. At this evaluation meeting, it is not just an ordinary meeting, but each department coordinator reports on the activities that have been carried out to the leadership regarding the work plan program that has been carried out or if there are problems in the department.

What has been done by PCNA West Jenangan, Ponorogo regarding the leadership function in a community organization according to Syamsu Q. Badu and Novianty Djafri in his book Organizational Leadership and Behavior, namely: (a) planning or looking forward, (b) organizing, (c) moving or encouraging, (d) supervision [21].

Pioneering leadership of women in developing Islamic community organizations is needed. as the statement of Ohorella et al. "Since the 19th century, many women have been shackled from old-fashioned customs, so they feel excluded from society and in the education sector, backward, in terms of Javanese konco wingking. In the late 19th century Indonesians from top to bottom began to make overall improvements and changes were not intended only for men but women also needed to be improved [22]. Awareness regarding the important role of women in various opportunities with the holding of organizations. The community leader of the Nasyiatul 'Aisyiyah branch, which is devoted to women through the organization, is expected to uphold the degree of women. Women also have the right to seek knowledge and preach because a mother's role is very important wherever she is, so a mother can influence anyone.

\subsection{Supporting Factors and Observers of Women's Pioneering in Public Leadership and Development of Islamic Community Organizations PCNA Experience West Jenang Ponorogo East Java Indonesia}

Women in carrying out their leadership there must be obstacles found. Even though obstacles are not a big problem, they can be used as an evaluation material in the future so that they become better. In addition, there are obstacles, of course, there is support that can facilitate an activity. The supporting factors of women's leadership in developing Islamic community organizations are: 1) getting permission from family, 2) friends with one voice and one commitment, 3) cleverly dividing time between organizations and becoming a housewife. While the inhibiting factors are 1) minimal cadre, 2) the age of mothers who are still productive in working and have offspring, 3) maternity leave continues until delivery and the child can be visited or left behind.

Leadership by involving women, then that's where women will play an important role and have a positive impact. As Jamharu and Ismatu Ropi's statement that "If in an Islamic organization such as Muhammadiyah Aisyiyah and Nasyiatul Aisyiyah contributed in the initial placement of women's involvement in leadership, education, social services, health, and other public spaces would further enhance the view that there are close roots in CSO 
participation. Islam in realizing gender equality and equality in Indonesia [23].

\subsection{Results of Women's Pioneering in Public Leadership and Development of Islamic Community Organizations PCNA Experience West Jenangan Ponorogo, East Java, Indonesia}

The role of women has changed from time to time[24] from the beginning of the domestic role as a housewife and a lack of human resources to have higher education at the level of a doctor and have a public role in state and community organizations.

The result of the development of Islamic community organizations in Nasyiatul Aisiyah of West Jenangan is to establish several new branches so that under the broader community organizations, women are able to speak in the public sector in the world of education, society, and government. The organization becomes a medium for exchanging experiences and skills for the meeting to improve Human Resources so that they are more confident and useful in the public sector. The role of Nasyiatul Aisyiyah in the end in social values, social status, educational communication, and work experience.

Through social organizations, women will tend to experience changes and better relationships with other communities, and there will be changes in mindset, advancing skills. Women's social status will be better without a sense of wanting to rival the position of men, which occurs more on social harmony in the family rather than discriminatory. The development of public communication for women in organizations will support good and effective communication within the family and community.

\section{CONCLUSION}

The pioneering role of women's leadership in developing Islamic community organizations is carried out by Nasyiatul Aisyiyah west Jenangan which shows that women are able to play a role in the public sector in the fields of education, religion, social, culture and economics as evidenced by the formation of work teams by implementing leadership functions including a) planning or looking forward in the form of periodic work programs, b) organizing, c) mobilizing or encouraging, d) supervision. Indicator of the implementation of the work program in the field of da'wah is conducting body care training, the field of regeneration and organization is to provide guidance for cadres Nasyiatul Aisyiyah, from social and economic aspects is to hold a bazaar or establish a business center "DINAR" (shining rice), from the field of communication and information there is a publishing bulletin NA, from the field of education and culture to become Islamic Education Tutors for every branch in Jenangan Sub district, from the field of consolidation the leadership section is to provide guidance and quality development for cadres, from the work program of secretariat there is an organization profile and the financial administration program is to create organizational independence with entrepreneurship.

Supporting factors are the support of the husband, solid members, and support of the surrounding community, while the obstacle is the lack of cadres, the busyness, and difficulties in managing women's time in their dual roles in the domestic and public sectors

The results of women's leadership in developing the Islamic community organization Nasyiatul 'Aisyiyah west Jenangan Ponorogo is carried out in accordance with the program that has been prepared and planned. The results of the development are proven by the increase in the number of branches which were originally four to seven branches, and the women members of Nasyiatul Aisyiyah were able to engage in any environment both in the educational environment, in the community and in government. The existence of Nasyiatul Aisyiyah women is able to develop themselves and manage community organizations such as in the field of public speaking as evidenced by how dare mothers speak in public and lead in various events or events. As well as success in the ability of community management with various innovative activities for women such as establishing business centers, becoming a TPA teaching team for each branch, bazaar in several events, FKD, participating in various competitions, and so on.

\section{REFERENCES}

[1] A. I. Sakina, "Menyoroti Budaya Patriarki Di Indonesia," Share Soc. Work J., vol. 7, no. 1, pp. 7180., 2017.

[2] I. Ahdiah, "Peran-Peran Perempuan Dalam Masyarakat," academica, vol. 5, no. 2, p. 8, 2013.

[3] A. Prantiasih, "Reposisi Peran dan Fungsi Perempuan,” J. Ilm. Pendidik. Pancasila Dan Kewarganegaraan, vol. 27, no. 1, p. 6, 2016.

[4] K. Logman, D. Jessica, D. L. Bray, and W. Liddell, "How organizational culture shapes women's leadership experiences," Adm. Sci., vol. 8, no. 2, p. 8, 2018.

[5] Depag RI, Al-qur'an Tajwid dan terjemah. Bandung: Marwah, 2009.

[6] S. Zakaria, "Kepemimpinan Wanita Dalam Perspektif Hukum Islam," Khazanah, vol. 6, no. 1, p. 69, 2013.

[7] A. R. Syam, "Konsep Kepemimpinan Bermutu Dalam Pendidikan Islam," J. -Tadib, vol. 12, no. 2, p. 50, 2017.

[8] T. Murti, Sejarah Kebudayaan Islam. Ponorogo: Gontor Press, 2012. 
[24] E. Ismawati, "The Status and the Roles of Javanese Women in Indonesian Literary Texts and in the Reality," J. Masy. Dan Budaya, vol. 2, no. 2, pp. 223236, 2018.

[10] K. Kasiran, Metodologi Penelitian KualitatifKuantitatif. Malang: UIN Maliki PRess, 2010.

[11] K. Narbuko and A. Achmadi, Metodelogi Penelitian. Jakarta: PT. Bumi Aksara, 2009.

[12] A. D. Wulansari, Penelitian Pendidikan. Ponorogo: STAIN Po Press, 2012.

[13] S. Suharsimi, Prosedur Penelitian Suatu Pendekatan Praktek. Jakarta: Rineka Cipta, 2002.

[14] L. J. Moleong, Metodologi Penelitian Kualitatif. Bandung: PT. Remaja Rosdakarya, 2006.

[15] S. Sugiyono, Metode Penelitian Kuantitatif, Kualitatif dan R \&D, IV. Bandung: ALFABETA, 2016.

[16] N. Annisa, "Preferensi Filantropi Perempuan pada Nasyiatul,” J. Indo-Islam., vol. 1, no. 2, pp. 273-309, 2012.

[17] M. Allison and J. Kaye, Perencanaan Strategis Bagi Organisasi Nirlaba. Indonesia: Yayasan Pustaka Obor, 2005.

[18] S. Dennis, T. R. Kuhn, and K. Kärreman, "The communicative constitution of organization, organizing, and organizationality," Organ. Stud., vol. 40, no. 4, pp. 147-496, 2019.

[19] B. Patricia, E. Schofer, and W. Longhofer, "Organizing for education: A cross-national, longitudinal study of civil society organizations and education outcomes," Volunt. Int. J. Volunt. Nonprofit Organ., vol. 29, no. 3, pp. 526-540, 2018.

[20] A. K. Khan, S. Moss, S. Quratulain, and I. Hameed, "When and how subordinate performance leads to abusive supervision: A social dominance perspective," J. Manag., vol. 44, no. 7, pp. 2801-2826, 2018.

[21] S. Q. Badu and N. Djafri, Kepemimpinan Dan Perilaku Organisasi. Gorontalo: Ideas Publishing, 2017.

[22] G. A. Ohorella, dkk, Peranan Wanita Indonesia Dalam Masa Pergerakan Nasional. Jakarta: Direktur Jenderal Kebudayaan, 1992.

[23] J. Jamhari and I. Ropi, Citra perempuan dalam Islam: pandangan ormas keagamaan. Jakarta: Gramedia Pustaka Utara, 2003. 